\title{
EFFECT OF GERMINATION PROCESS ON THE CHEMICAL AND BIOLOGICAL ACTIVE COMPOUNDS OF BARLEY AND OAT GRAINS

\author{
EL-Refai, A. A. ${ }^{1}$; Amal M. El-Bastawesy ${ }^{2}$ and Eman S. El- Ashaal ${ }^{2}$ \\ 1- Food Industries Dept., Fac. of Agric., Mansoura Univ., Egypt \\ 2- Food Technology Research Institute, Agric. Res. Center, Giza
}

\begin{abstract}
In recent years, cereals especially barley and oat grains have attracted researches and commercial attention mainly due to their high contents of dietary fibers, $\beta$ - glucan and phenolic compounds with high antioxidant activates. Therefore, a preliminary study was carried out to estimate the components of raw barley and oat grains as well as, the effect of germination process on chemical composition and biological active compounds. The obtained results reveled that the germination process had a great role on the efficiency of chemical composition of selected cereal grains. A large number of negatively valued components in the grains such as crude fibers and starch contents of barley and oat decreased with prolonging the germination time process and the reduction of their contents due to the activity of $\alpha-$ amylase enzymes during germination process which led to an increase in total sugars. Phytic acid decline with germination time increase.

Otherwise, protein contents gradually increased with prolonging the germination period being 15.24 and $12.96 \%$ after three days for barley and four days for oat, respectively. Prolonging the germination time increased the minerals content of barley and oat grains and improved the bioavailability of essential minerals. Moreover, $\beta$-glucan contents declined with increasing the germination time process.

Prolonging germination period increased total phenolic compounds, flavonoids contents and antioxidant activity, Catechin and pyrogallol were the major free phenolic compounds that existed in raw and germinated barley and oat grains. Nicotinic acid and Vit. B1 were the most abundant B complex vitamins in raw barley and oat grains and they highly increased during the germination period more than two folds recording 120.81 and $145.56 \mathrm{mg} / 100 \mathrm{~g} \& 335.21$ and $441.62 \mathrm{mg} / 100 \mathrm{~g}$, respectively.

Finally, it could be concluded that germination process had positive effects to improve the bioactive compounds contents as total phenolic and flavonoids compounds, antioxidant activity and an increase in bioavailability of essential minerals and a higher content of Vit. B complex of barley and oat grains.
\end{abstract}

\section{INTRODUCTION}

Cereals are considered as one of the most important economic and food commodities in the world. Barley (Hordeum vulgare L.) is a major cereal grain, as a member of the grass family. Also, barley is a major crop for malting, brewing and for food production industries in the developed countries and it is utilized as fodder crop in the less developed and developing countries. Barley is a typical cereal grains composed primarily of starch, protein, fibers, lipids and minerals (Akar et al., 2004).

The common oat (Avena sativa) is one of the species of cereal grain grown for its seed, being known to provide healthy human with nutrients. Oats have been grown since thousands of years, mainly as an animal feed 
crop, but during the 19th century oats won acceptance as part of the human diets (Webster, 1986). At that time oats were generally consumed as oatmeal, but today oats can be found in various food products, as breakfast cereals, beverages, bread and infant foods (Johansson et al., 2007).

The barley accounts for $12 \%$ of the world's total cereal production and occupies the fourth position with respect to grain production after wheat, rice and corn, whereas, oats are the fifth largest cereal crop in the world (Jadhav et al., 1998).

In Egypt, the average total annual area cultivated with barley grains are 87752 hectar which produced annually, 117113 tons (FAO, 2010).

Barley grain is an excellent source of soluble and insoluble dietary fibers and other bioactive constituents, such as vitamin E (including toco-tri-enols), minerals, and phenolic compounds (Qureshi et al., 1986 and 1991). Oats are also a good source of various bioactive compounds, as antioxidants such as vitamin E, phytic acid and phenolic compounds (Peterson, 2001). Barley and oat are gaining renewed interest as a functional food ingredient due to the fact that barley and oat grains are a rich source of $\beta$ - glucans, which represented $3-11 \%$ in barley and $3-7 \%$ in oats and its percentage varies with cultivar and environmental effects (Soares et al., 2007). HÜbner et al. (2010) showed that B-glucan content in barley and oat was 3.8 and $4.2 \%$, respectively.

The total phenolic content of barley varieties ranged from 0.881 to 1.457 $\mathrm{mg} / \mathrm{g}$ as gallic acid. Also, the total flavonoids content of barley grains ranged from 0.325 to $0.527 \mathrm{mg} / \mathrm{g}$ and antioxidant activity of barley was $21.00 \mu \mathrm{g} / \mathrm{g}$. (Holtekjolen et al., 2006 and Ragaee et al., 2006).

Germination process is a natural process occurring during growth period of seeds in which they meet the minimum conditions for growth and development (Sangronis et al., 2006). Germination process has long been used as a way to modify taste, appearance and technological properties of grains (Belitz et al., 2001) As well as, it causes breakdown in some components in barley and oat especially in B-glucan contents which decreased during germination process to $2.98 \%$ (Al-Rdaddi, 2008) due to the activity of B-gluconase enzymes. Starch contents decreased due to the activity of $\alpha$-amylase enzymes. As well as, protein contents of steeped oats also increased (Tian et al., 2010). Phytic acid content of germinated barley and oats after $96 \mathrm{hrs}$. decreased to $0.441 \%$ and $0.588 \%$, respectively HÜbner et al. (2010).

Germination process significantly led to increasment the total phenolic content and antioxidant activity of barley. Moreover, the antioxidant activity increased with in $12 \mathrm{hrs}$. of germination process after $12 \mathrm{hrs}$. (Sharma and Singh Gujral, 2010).

Therefore, this work was a trial to utilize of barley and oat grains which represent plentiful amounts as main sources of dietary fibers mainly, Bglucan and other nutrients and to study the effect of soaking and germination processes on the chemical and nutritional properties of barley and oat grains. 


\section{MATERIALS AND METHODS}

\section{Materials}

Barley grains (Hordeum rulgare L.), six rowed barley, Giza 132 were obtained from Barley Research Dept. Crop Res. Inst., ARC, Giza, Egypt.

Oat (Avena sativa) grains were obtained from Food and Feed Res. Inst., ARC, Giza, Egypt.

Methods

\section{Preparation of raw materials}

Malt was prepared from barley and oat grains as follows:

Dry grains were washed and soaked in tap water (1:2 w/v) at room Temp. $\left(25 \pm 5^{\circ} \mathrm{C}\right)$ for $8 \mathrm{hrs}$. The grains were spread on wet surface at $25{ }^{\circ} \mathrm{C}$ for $2: 3$ days for barley and 3: 4 days for oat until they had germinated. During the germination period, the grains were sprayed and then dried at $55^{\circ} \mathrm{C}$ for $8 \mathrm{hrs}$. to prevent the germination development. The dried barley and oat sprouts were milled using a Moulinex mill machine to a particles size less than 80 mesh.

\section{Analytical Methods}

\section{Gross chemical composition}

- Moisture, ash, protein, fat and crude fibers contents were determined according to the methods described in the A.O.A.C. (2007).

- Minerals content were determined after dry ashing according to the method described in the A.O.A.C. (2007), using atomic absorption amanitas (Perkin - Elmer, Model 3300, USA).

-Total sugars were extracted from the samples by water and clarified by lead acetate. Sodium oxalate was used to precipitate the excess of lead acetate. Total and reducing sugars were determined in the clarified solution by Somogy (1952) and Nelson (1974).

-Starch was determined according to the method described in the A.O.A.C. (2007).

- Phytic acid was determined according to the method described by Mohamed et al. (1986)

- Dietary fibers fractions were determined using Tecator fibretic system according to the method described by Van Soest and Bretson (1979).

- $\beta$-glucan was determined according to the method described by Carr et al. (1990).

- The total phenolic compounds were determined with Folin - Ciocalteu reagent using gallic acid as a standard according to the method described by Danial and George (1979).

-Total flavonoids were determined accordiong to the method described by Zhuang et al. (1992).

-Phenolic compounds were fractionated and identified by HPLC Hewllet Packared (series 1050) according to the method of Goupy et al. (1999).

- The antioxidant activity of phenoilc compounds was measured in terms of hydrogen donating or radical scavenging ability, using the stable radical 
DPPH (2, 2'-Diphenyl-1-picrylhydrazyl) according to the colorimetric method of Brand-Williams et al. (1995).

-Vit. B-complex were determined according to the method described by Batifoulier et al.(2005) with slight modification using variable wavelength detector (VWD) instead of florescence detector, VWD set at $280 \mathrm{~nm}$. HPLC Agilent 100 series.

\section{RESULTS AND DISCUSSION}

\section{Effect of germination process on gross chemical composition of barley and oat grains}

Data in Table (1) reveal no changes occurred in moisture and ash contents of barley and oats grains during germination period. Meanwhile, protein contents (12.15 and $11.13 \%$ ) gradually increased with increasing the germination period being 15.24 and $12.96 \%$ after three days for barley and four days for oat, respectively. increasment in protein content may be attributed to the dry weight losses through respiration during malting process. These results are in agreement with those reported by Peterson (1998). On the other hand, fat contents of barley and oat grains decreased from 3.6 to $1.53 \%$ and 7.5 to $6.1 \%$, respectively. The decreasment in lipid content probably results in part from lipase catalyzed degradation triacylglycerides to free fatty acids (FFA) and glycerol and the further oxidation of the FFA into non lipid products (Peterson, 1998).

Table (1): Effect of germination process on chemical composition of barley and oat grains (on dry weight basis)

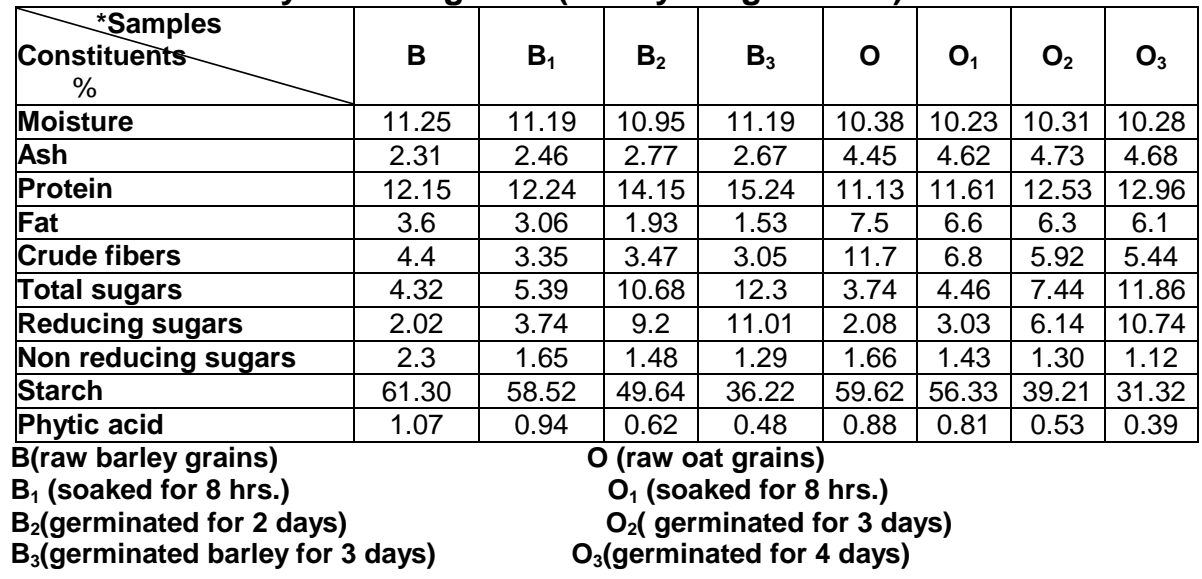

Crude fibers content of barley and oats grains decreased from 4.4 to $3.05 \%$ and 11.7 to $5.44 \%$, respectively. Whereas, the starch content decreased from 61.3 to $36.22 \%$ and 59.62 to $31.32 \%$ for barley and oats grains, respectively. As shown in Table (1), the total and reducing sugars contents of barley (4.32 and $2.02 \%$ ) and oats (3.74 and $2.08 \%$ ) grains increased during germination period being $12.3 \%$ and $11.01 \% \& 11.86$ and 
$10.74 \%$, respectively. The data of starch contents are in accordance with those reported by Tian et al. (2010) who reported that the reduction of starch content was due to the activity of $\alpha-$ amylase enzymes during germination process and which causes an increase in total sugars. Moreover, the non reducing sugars decreased from 2.3 to $1.29 \%$ and 1.65 to $1.12 \%$ for barley and oats grains, respectively.

Phytic acid content of barley and oat grains decreased from 1.07 to $0.48 \mathrm{mg} / 100 \mathrm{~g}$ and 0.88 to $0.39 \mathrm{mg} / 100 \mathrm{~g}$ throughout germination period, respectively. A large number of negatively valued components in the seed such as phytic acid decline with increasing time of germination and the decrease could be attributed to an increase in phytase activity as germination progressed. The data of phytic acid contents are enclosed with those reported by Larsson \& Sandberg (1992).

Generally, from the aforementioned data it could be clearly concluded that germination process had a great role on the efficiency of chemical composition of selected cereal grains. Increasing germination period decreased fat, crude fibers and starch contents due to the activities of hydrolysis enzymes.

Effect of germination process on minerals content of barley and oat
grains

Data presented in Table (2), show that $\mathrm{Mg}(36.14$ and $54.37 \mathrm{mg} / 100 \mathrm{~g})$ and $\mathrm{Na}(73.39$ and $83.58 \mathrm{mg} / 100 \mathrm{~g})$ contents in raw barley and oat grains increased while at end of germination period being $227.52 \& 116.45$ $\mathrm{mg} / 100 \mathrm{~g}$ and $314.23 \& 103.48 \mathrm{mg} / 100 \mathrm{~g}$, respectively. Slightly changes in $\mathrm{Zn}$, $\mathrm{Mn}$ and Fe contents occurred. On the other hand, Ca content of barley (38.94 $\mathrm{mg} / 100 \mathrm{~g}$ ) increased more than 3 folds during the germination process being $129.84 \mathrm{mg} / 100 \mathrm{~g}$ after three days. Meanwhile, slightly increased recorded of $\mathrm{Ca}$ oat contents $(107.56 \mathrm{mg} / 100 \mathrm{~g})$ after four days being $116.45 \mathrm{mg} / 100 \mathrm{~g}$ (Table, 2).

Table (2): Effect of germination process on minerals content of barley and oat grains (on dry weight basis)

\begin{tabular}{|l|c|c|c|c|c|c|c|c|}
\hline $\begin{array}{c}\text { *Samples } \\
\text { Minerals } \\
(\mathrm{mg} / 100 \mathrm{gm})\end{array}$ & $\mathbf{B}$ & $\mathbf{B}_{1}$ & $\mathbf{B}_{2}$ & $\mathbf{B}_{3}$ & $\mathbf{O}$ & $\mathbf{O}_{\mathbf{1}}$ & $\mathbf{O}_{2}$ & $\mathbf{O}_{3}$ \\
\hline $\mathbf{M g}$ & 36.14 & 64.59 & 134.06 & 227.52 & 54.37 & 59.28 & 74.24 & 116.45 \\
\hline $\mathrm{Na}$ & 73.39 & 141.61 & 230.29 & 314.23 & 83.58 & 97.31 & 100.78 & 103.48 \\
\hline $\mathbf{Z n}$ & 0.29 & 0.32 & 0.31 & 0.33 & 0.36 & 0.37 & 0.38 & 0.47 \\
\hline $\mathbf{M n}$ & 0.170 & 0.185 & 0.187 & 0.188 & 0.314 & 0.325 & 0.358 & 0.457 \\
\hline $\mathbf{F e}$ & 0.829 & 0.817 & 0.832 & 0.836 & 1.11 & 1.14 & 1.15 & 1.16 \\
\hline $\mathbf{C a}$ & 38.94 & 77.21 & 108.46 & 129.84 & 107.56 & 113.42 & 114.42 & 116.45 \\
\hline $\mathbf{K}$ & 226.86 & 245.36 & 270.03 & 307.52 & 83.58 & 85.20 & 92.91 & 122.41 \\
\hline
\end{tabular}

${ }^{\star}$ See Table (1)

Potassium contents increased from 226.86 to $307.52 \mathrm{mg} / 100 \mathrm{~g}$ and 83.58 to $122.41 \mathrm{mg} / 100 \mathrm{~g}$ for barley and oat grains, respectively after the germination process. These results are in agreement with those reported by Hübner et al. (2010) who found that minerals content of germinated barley 
and oat grains can be influenced by the minerals content of the steeping water.

Accordingly, from the above data it could be concluded that the more germination time, the more minerals content of barley and oat grains was observed, because of phytase activity on phytates which liberates the minerals from phytates complex in free mode.

\section{Effect of germination process on dietary fibers fraction and $\beta$-glucan contents of barley and oat grains}

Neutral detergent fibers (NDF), acid detergent fibers (ADF) and acid detergent lignin (ADL) were fractionated as well as, cellulose and lignin contents were also determined and the results are shown in Table (3).

Data in Table (3) reveal that NDF, ADF and ADL contents of barley were $(18.94,8.19$ and $1.56 \%$, respectively) and $(24.09,12.48$ and $2.75 \%$ in oat, respectively). These decreased during germination period being 16.06, 7.19 and $1.11 \%$ for barley after three days and $20.98,11.86$ and $2.38 \%$ for oat after four days, respectively. Whereas, hemicelluloses and cellulose contents decreased with increasing germination period till two days for barley (7.49 and $5.83 \%$ ) and three days for oat (6.09 and $6.41 \%)$. After that they recorded 8.87 and $6.08 \%$ for barley and 9.12 and $9.48 \%$ for oat grains, respectively.

Meanwhile, lignin content in barley and oat (0.96 and $1.72 \%)$ decreased during steeping process being $0.61 \%$ in barley and $1.11 \%$ in oat. After that its contents raised till two days in barley being $0.71 \%$ then decreased with increasing the germination period being $0.57 \%$ for barley and $1.52 \%$ for oat (Table, 3 ).

Table (3): Effect of germination process on dietary fiber fractions and $\beta$ glucan contents of barley and oat grains(on dry weight basis)

\begin{tabular}{|l|c|c|c|c|c|c|c|c|}
\hline $\begin{array}{l}\text { *Samples } \\
\text { Constituents\% }\end{array}$ & $\mathbf{B}$ & $\mathbf{B}_{\mathbf{1}}$ & $\mathbf{B}_{\mathbf{2}}$ & $\mathbf{B}_{\mathbf{3}}$ & $\mathbf{O}$ & $\mathbf{O}_{\mathbf{1}}$ & $\mathbf{O}_{\mathbf{2}}$ & $\mathbf{O}_{\mathbf{3}}$ \\
\hline NDF & 18.94 & 17.14 & 14.73 & 16.06 & 24.09 & 20.86 & 14.73 & 20.98 \\
\hline ADF & 8.19 & 7.28 & 7.24 & 7.19 & 12.48 & 9.81 & 8.48 & 11.86 \\
\hline ADL & 1.56 & 1.17 & 1.41 & 1.11 & 2.75 & 2.00 & 2.07 & 2.38 \\
\hline Hemicelluloses & 10.75 & 9.86 & 7.49 & 8.87 & 11.61 & 11.05 & 6.09 & 9.12 \\
\hline Cellulose & 6.63 & 6.11 & 5.83 & 6.08 & 9.73 & 7.81 & 6.41 & 9.48 \\
\hline Lignin & 0.96 & 0.61 & 0.71 & 0.57 & 1.72 & 1.11 & 1.24 & 1.52 \\
\hline Total $\boldsymbol{\beta}$ glucan & 4.48 & 4.02 & 3.86 & 3.71 & 3.15 & 2.94 & 2.57 & 2.43 \\
\hline Soluble $\boldsymbol{\beta}$ glucan & 2.77 & 2.96 & 3.11 & 3.21 & 1.39 & 1.51 & 1.81 & 1.93 \\
\hline $\begin{array}{l}\text { Non soluble } \\
\text { glucan }\end{array}$ & 1.71 & 1.01 & 0.75 & 0.50 & 1.59 & 1.44 & 0.76 & 0.43 \\
\hline
\end{tabular}

${ }^{*}$ See Table (1)

NDF: Neutral detergent fiber (Cellulose, hemicelluloses, lignin)

ADF: Acid detergent fiber (Cellulose, lignin) ADL: acid detergent lignin

On the other hand, the total and insoluble $\beta$-glucan contents of barley and oat grains (4.48 and $3.15 \% \& 1.71$ and $1.59 \%$, respectively) decreased during germination period being 3.71 and $2.43 \%$ \& 0.50 and $0.43 \%$, respectively (Table,3). The breakdown of $\beta$-glucan during germination process caused by $\beta$-glucanase enzymes. Soluble $\beta$-glucan contents slightly increased in barley and oat during germination from 2.77 to $3.21 \%$ and 1.39 
to $1.93 \%$, respectively. The data of $\beta$-glucan contents are in accordance with those reported by Hübner et al. (2010.)

Generally, $\beta$-glucan contents of barley and oat grains slightly declined with increasing the germination time.

Effect of germination process on total phenolic compounds, antioxidant activity and flavonoids contents of barley and oat grains

Some bioactive compounds namely, polyphenols, flavonoids contents and antioxidant activity were determinated and the results are presented in Table (4).

The results in Table (4) show that the total phenolic compounds $(0.791$ and $0.62 \mathrm{mg} / \mathrm{g}$ ) and antioxidant activity (3.68 and $4.32 \%$ ) of barley and oat grains gradually increased with increasing the germination period being 2.01 and $1.93 \mathrm{mg} / \mathrm{g} \& 9.43$ and $11.28 \%$ after three days for barley and four days for oat grains, respectively. Increasing in total phenolic compounds and antioxidant activity may be attributed to the better extractability of phenolic compounds from the kernel structures after germination. In addition, hydrolytic enzymes can lead to the release of bound phenolic compounds, mainly the phenolic acids are associated to lignin and arabinoxylans. The results of total phenolic compounds are in agreement with those reported by Sharma and Singh Gujral (2010). Meanwhile, the increase of antioxidant activity could be due to the development of such non-enzymatic browning products as Maillard products, which can also act as antioxidants, particularly melanoidins. The data of antioxidant activity contents are in accordance with those reported by Dvořáková et al. (2008).

The flavonoids content in barley and oat grains $(0.563$ and $0.46 \mathrm{mg} / \mathrm{g})$ gradually increased with increasing the time of germination process being 1.43 and $1.27 \mathrm{mg} / \mathrm{g}$ (Table, 4).

Generally, from the data presented in Table (4), it could be clearly observed that increasing germination period increased total phenolic compounds, antioxidant activity and flavonoids contents.

Table (4): Effect of germination process on total phenolic compounds, antioxidant activity and flavonoids content of barley and oat grains(on dry weight basis)

\begin{tabular}{|l|c|c|c|c|c|c|c|c|}
\hline \multicolumn{1}{|c|}{${ }^{*}$ Samples } & $\mathbf{B}$ & $\mathbf{B}_{1}$ & $\mathbf{B}_{2}$ & $\mathbf{B}_{3}$ & $\mathbf{O}$ & $\mathbf{O}_{\mathbf{1}}$ & $\mathbf{O}_{\mathbf{2}}$ & $\mathbf{O}_{3}$ \\
\hline $\begin{array}{l}\text { Constituents } \\
\text { (as gallic acid) }(\mathrm{mg} / \mathrm{g})\end{array}$ & 0.791 & 0.80 & 1.64 & 2.01 & 0.62 & 0.73 & 1.56 & 1.93 \\
\hline $\begin{array}{l}\text { Antioxidant activity \% } \\
\text { (as DPPH) }\end{array}$ & 3.68 & 4.22 & 5.43 & 9.43 & 4.32 & 5.93 & 8.78 & 11.28 \\
\hline $\begin{array}{l}\text { Flavonoids } \\
\text { (mg/g) }\end{array}$ & 0.563 & 0.61 & 1.15 & 1.43 & 0.46 & 0.55 & 0.813 & 1.27 \\
\hline
\end{tabular}

${ }^{*}$ See Table (1) 


\section{Effect of germination process on phenolic compounds fractions of barley and oat grains}

Phenolic compounds of barley and oat grains were separated and identified by HPLC and the results are presented in Table (5).

The results in Table (5) reveal that phenolic compounds of barley and oats varied with the difference in steeping and germination stages. Catechin and pyrogallol were the major free phenolic compounds that existed in raw and germinated barley and oat grains. Catechin $(30.98$ and $32.60 \mathrm{mg} / 100 \mathrm{~g})$ and pyrogallol (43.05 and $21.49 \mathrm{mg} / 100 \mathrm{~g}$ ) increased during germination period being 40.17 and $114.93 \mathrm{mg} / 100 \mathrm{~g}$ after three days for barley and 189.21 and $159.81 \mathrm{mg} / 100 \mathrm{~g}$ after four days for oat grains, respectively. Whereas, gallic acid $(0.99$ and $0.63 \mathrm{mg} / 100 \mathrm{~g})$, chlorogenic (2.88 and 1.08 $\mathrm{mg} / 100 \mathrm{~g})$ and catechol $(2.40$ and $3.05 \mathrm{mg} / 100 \mathrm{~g})$ were found in traces then, increased gradually during the germination period being 5.11 and 1.17 $\mathrm{mg} / 100 \mathrm{~g} ; 23.50$ and $22.49 \mathrm{mg} / 100 \mathrm{~g}$ and 8.62 and $8.56 \mathrm{mg} / 100 \mathrm{~g}$ for barley and oat grains, respectively (Table, 5). $\mathrm{P}-\mathrm{OH}$ benzoic, ferulic and hespertin were detected after steeping and germination process recording 3.11 and $2.19 \mathrm{mg} / 100 \mathrm{~g} ; 2.46$ and $2.29 \mathrm{mg} / 100 \mathrm{~g}$ and 4.34 and $2.40 \mathrm{mg} / 100 \mathrm{~g}$ for barley and oat, respectively. On the other hand, caffeic and protocatchoic of raw barley and oat grains disappeared during steeping and germination process. These results are in accordance with those reported by Beart et al. (1985) who reported that the variation in fraction of phenolic compounds should be caused by an increase of enzymatic activity during steeping and germination processes.

Table (5): Effect of germination process on phenolic compounds fraction of barley and oat grains(on dry weight basis)

\begin{tabular}{|l|c|c|c|c|c|c|c|c|}
\hline \multicolumn{1}{|c|}{${ }^{*} \begin{array}{l}\text { Phenotic } \\
\text { compounds } \\
\text { (mg/100g) }\end{array}$} & $\mathbf{B}$ & $\mathbf{B}_{1}$ & $\mathbf{B}_{2}$ & $\mathbf{B}_{3}$ & $\mathbf{O}$ & $\mathbf{O}_{1}$ & $\mathbf{O}_{2}$ & $\mathbf{O}_{3}$ \\
\hline Gallic acid & 0.99 & 2.53 & 2.77 & 5.11 & 0.63 & 0.68 & 0.82 & 1.17 \\
\hline Catechin & 30.98 & 30.92 & 36.02 & 40.17 & 32.60 & 17.70 & 72.24 & 114.93 \\
\hline Pyrogallol & 43.05 & 50.42 & 178.01 & 189.21 & 21.49 & 30.52 & 117.97 & 159.81 \\
\hline Chlorogenic & 2.88 & 5.09 & 18.81 & 23.50 & 1.08 & 1.30 & 22.49 & 29.97 \\
\hline P-OH Benzoic & - & 1.37 & 2.51 & 3.11 & - & 1.14 & 1.24 & 2.19 \\
\hline Catechol & 2.40 & 2.84 & 4.23 & 8.62 & 3.05 & 4.92 & 6.63 & 8.56 \\
\hline Vanillic & - & 6.45 & 8.15 & - & - & 1.77 & 3.31 & - \\
\hline Ferulic & - & 0.72 & 1.00 & 2.46 & - & 0.22 & 0.57 & 2.29 \\
\hline Hespertin & - & 0.41 & 0.74 & 4.34 & - & 0.56 & 2.22 & 2.40 \\
\hline Caffeic & 0.42 & - & - & - & 0.98 & - & & - \\
\hline Syringic & 1.02 & 2.88 & 6.38 & - & 0.86 & 1.63 & 3.68 & - \\
\hline P-coumaric & - & - & 1.72 & - & - & - & - & - \\
\hline Protocatchoic & 2.88 & - & - & & 0.24 & - & - & - \\
\hline Chrisin & - & - & - & - & - & 0.38 & - & - \\
\hline Hesperdin & - & - & - & - & - & 0.89 & - & - \\
\hline *See Table (1) & & & & & & & & \\
\hline
\end{tabular}

${ }^{*}$ See Table (1) 


\section{Effect of germination process on vitamin B contents of barley and oat grains}

As recorded in Table (6), nicotinic acid (60.82 and $71.23 \mathrm{mg} / 100 \mathrm{~g})$ and Vit. B1 (210.19 and $207.74 \mathrm{mg} / 100 \mathrm{~g}$ ) were the most abundant Vit. B complex in raw barley and oat grains and they highly increased during germination period more than two folds recorded 120.81 and 145.56 $\mathrm{mg} / 100 \mathrm{~g} \& 335.21$ and $441.62 \mathrm{mg} / 100 \mathrm{~g}$ after three days for barley and four days for oat grains, respectively. On the other hand, folic acid (3.55 and $12.67 \mathrm{mg} / 100 \mathrm{~g}$ ), pyridoxine (3.02 and $2.11 \mathrm{mg} / 100 \mathrm{~g})$, B12 (11.13 and 21.03 $\mathrm{mg} / 100 \mathrm{~g})$ and riboflavin $(3.17$ and $1.48 \mathrm{mg} / 100 \mathrm{~g})$ found in small amounts of raw barley and oat grains and also increased to 14.50 and18.83 mg/100g, 32.00 and $20.00 \mathrm{mg} / 100 \mathrm{~g}, 36.42$ and $50.76 \mathrm{mg} / 100 \mathrm{~g}$ and 4.13 and 2.24 $\mathrm{mg} / 100 \mathrm{~g}$ for germinated barley and oat grains, respectively (Table, 6). Increasing of Vit. B complex quantity could be due to the fact that, during germination, seeds synthesized vitamins for its development. These results are in accordance with those of Chavan (1989).

Table (6): Effect of germination process on B complex vitamins content of barley and oat grains(on dry weight basis)

\begin{tabular}{|l|c|c|c|c|}
\hline $\begin{array}{l}\text { Vit. B } \\
\text { complex fractions (mg/Toog) }\end{array}$ & $\mathbf{B}$ & $\mathbf{B}_{3}$ & $\mathbf{O}$ & $\mathbf{O}_{3}$ \\
\hline Nicotenic acid & 60.82 & 120.81 & 71.23 & 145.56 \\
\hline Folic acid & 3.55 & 14.50 & 12.67 & 18.83 \\
\hline Pyroxidine (B6) & 3.02 & 32.00 & 2.11 & 20.00 \\
\hline Cobalamin (B12) & 11.13 & 36.42 & 21.03 & 50.76 \\
\hline Thiamin (B1) & 210.19 & 335.21 & 207.74 & 441.62 \\
\hline Riboflavin (B2) & 3.17 & 4.13 & 1.48 & 2.24 \\
\hline
\end{tabular}

${ }^{*}$ See Table (1)

\section{REFERENCES}

Akar, T.; M. Avci and F. Dusanceli (2004). Barley: post harvest operations. http://www.FAO.Org/inplo/content compend/ text/ ch31. htm. Accessed on 15 August 2007.

Al - Rdaddi, Amaal S. (2008). Preparation and evaluation some functional foods using germinated barley grains and fractions. M. Sc, Thesis, Food Sci., Fac. of Home Economics., Saudi. Arabia.

A.O.A.C. (2007). Official Methods of Analysis of The Association of Official Analytical Chemists. 18th ED. Gaithersburg, Maryland, U.S.A.

Batifoulier, F.; M. Verny; C. Besson; C. Demigne and C. Remesy (2005). Determination of thiamine and its phosphate esters in rat tissues analyzed as thiochromes on RP- amide C16 column. J. Chrom. B., 8 (16): 67-72.

Beart, J.; T. Lilley and E. Haslam (1985). Polyphenol interactions. Part 2. Covalent binding of procyanidins to proteins during acid-catalysed decomposition; Observations on some polymeric proanthocyanidins. J. Chem. Soc. Perkin. Trans., 1439-1443. 


\section{EL-Refai, A. A. et al.}

Belitz, H.; W. Grosch; P. Schieberle (2001). Lehrbuch der Lebensmittelchemie, 5th edn. Springer, Berlin.

Brand-Williams, W.; M. Cuvelier and C. Berset (1995). Use of a free radical method to evaluate antioxidant activity. Lebensm. Wiss. Tech., 28: 2530.

Carr, J.; S. Glatter; J. Jeraci and B. Lewis (1990). Enzymic determination of $\beta$-glucan in cereal based food products. Cereal Chem., 67 (3): 226-229.

Chavan, J. and S. Kadam (1989). Nutritional improvement of cereals by sprouting. Crit Rev. Food Sci. Nutri., 28: 401-437.

Danial, H. and C. George (1979). Peach seed dormancy in relation to endogearus in inhibitor and applied growth substances. J. Amer. Soc. Hor. Sci., 97: 651- 655.

Dvoráková, M.; M. Douabier; M. Jurková; V. Kellner and P. Dostálek (2008). Comparison of antioxidant activity (Hordeum Vulgare L.) and malt extracts with the content of free phenolic compounds measured by high performance liquid chromatography coupled with coularray detector. J. Inst. Brew., 114 (2): 150- 159.

FAO (2010). FAO Stat. Database. Available from http://faostat.fao.org.

Goupy, P.; M. Hugues; P. Boivin and M. Amiot (1999). Antioxidant composition and activity of barley (Hordeum vulgare) and malt extracts and of isolated phenolic compounds. J. Sci. Fd. \& Agric., 79: 16251634.

Holtekjolen A.; C. Kinitz and S. Knutsen (2006). Flavanol and bound phenolic acid contents in different barley varieties. J. Agric \& Fd. Chem., 54: 2253.

HÜbner, F.; T. O' neil; K. Cashman and E. Arendt (2010). The influence of germination conditions on Beta- glucan, dietary fiber and phytate during the germination. Eur. Fd. Res. \&Tech.,231: 27-35.

Jadhav, S.; S. Lutz; V. Ghorpade and D. Salunkhe (1998). Barley: Chemistry and Value- Added Processing. Crit Review in Fd. Sci., 38 (2): 123-171.

Johansson, L.; P. Tuomainen; H. Anttila; H. Rita and L. Virkki (2007). Effect of processing on the extractability of oat $\beta$-glucan. Fd. Chem., 105: 1439-1445.

Larsson, M. and A. Sandberg (1992). Phytate reduction in oats during malting. J. Food Sci., 57 (4): 994-997.

Mohamed, A.; A. Ponnamperuma; J. Perea and Y. Hafez (1986). New chromophore for phytic acid determination. Cereal Chem., 63 (6): 475478.

Nelson, N. (1974). A photometric adaptation of the Somogy method for the determination of glucose. J. Biol. Chem., 135: 375-380.

Peterson, D. (1998). Malting oats: Effect on chemical composition of hulless and hulled genotypes. Cereal Chem., 75 (2): 230- 234.

Peterson, D.; C. Emmons and A. Hibbs (2001). Phenolic antioxidants and antioxidant activity in pearling fractions of oat groats. J. Cereal Sci., 33: 97-103.

Qureshi, A.; W. Burger; D. Peterson; and C. Elson (1986). The structure of an inhibitor of cholesterol biosynthesis isolated from barley. J. Biol. Chem., 261: 10544-10550. 
Qureshi, A.; N. Qureshi ; J. Wright; Z. Shen; G. Kramer; A. Gapor; Y. Chong; G. Dewitt; Ong, A.; Peterson, D. and Bradlow, B.( 1991). Lowering serum cholesterol in hypercholesterolemic humans by tocotrienols (palmvitee). Amer. J. Clinical Nutri., 53: 1021-1026.

Ragaee, S.; E. Abdel- Aal and M. Noaman (2006). Antioxidant activity and nutrient composition of selected cereals for food use. Food Chem., 98: 32-38.

Sangronis, E.; M. Rodriguez; R. Cava and A. Torres (2006). Protein quality of germinated Phaseolus vulgaris. Eur. Food Res. \& Tech., 222 (1): 144-148.

Sharma, P. and Singh Gujral, H. (2010). Antioxidant and polyphenols oxidase activity of germinated barley and its milling fractions. Food Chem., 120: 673-678. Soares, R.; A. Defrancisco; P. Rayas-Durat and V. Soldi (2007). Brazilian hull-less and malting barley genotypes: I. Chemical composition and partial characterization. J. Food Quality, 30: 357-371.

Somogy, M. (1952). Notes on sugar determination. Biol. Chem., 115: 195199.

Tian, B.; B. Xie; W. Shi; Y. Cai; T. Xu; S. Xue and Q. Deng (2010). Physicochemical changes of oat seeds during germination. J. Food Chem., 119: 1195-1200.

Van-Soest, P. and J. Bretson (1979). Systems of analysis for evaluation fibrous: Food Standardization of Analytical Methodology of Feeds. IDRC, Ottawa, CA., 49-60.

Webster, F. (1986). Oat utilization: Past, present and future. In: Oats: Chemistry and Technology. Association of Cereal Chem., 413 - 423.

Zhuang, X.; Y. Lu and G. Yang (1992). Extraction and determination of flavonoids in ginkgo. Chin. Herb. Med., 23: 122-124.

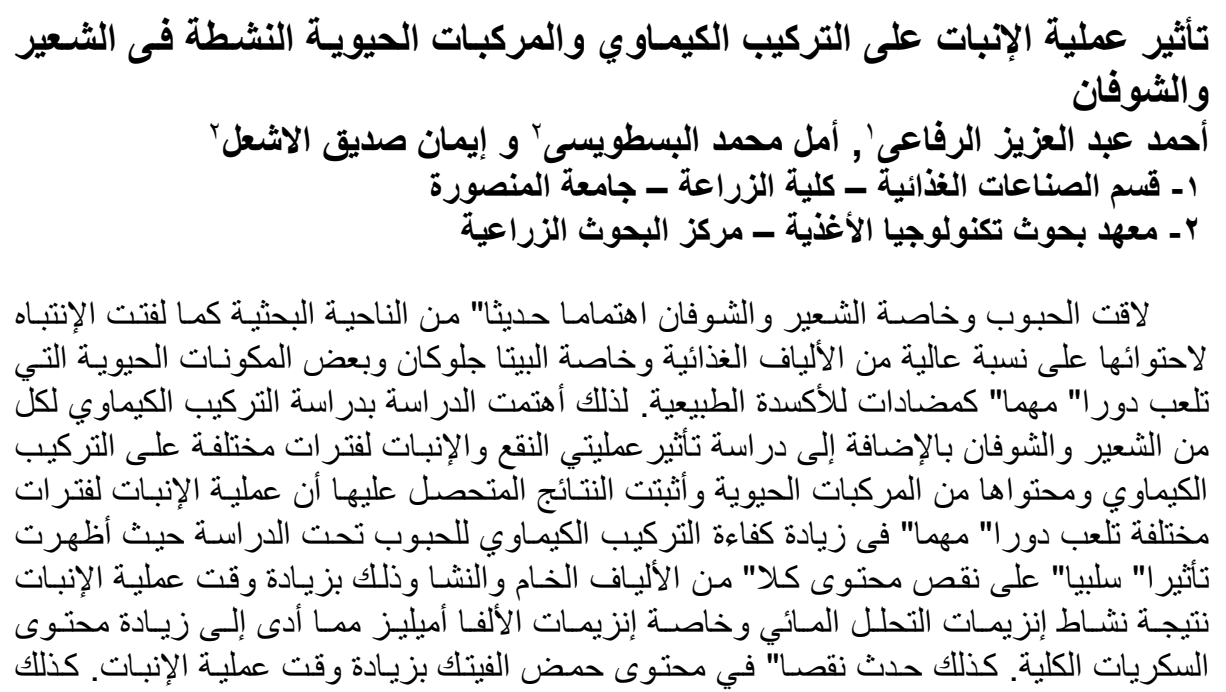




\section{EL-Refai, A. A. et al.}

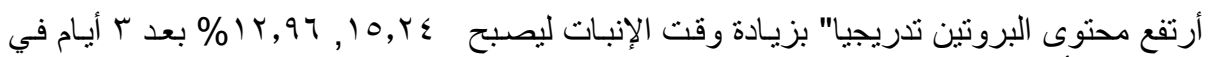

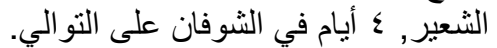

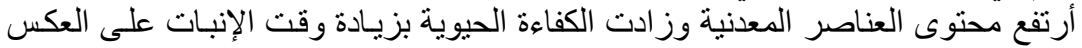

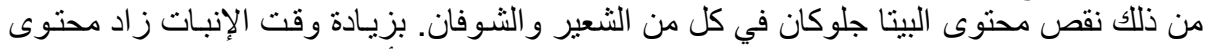

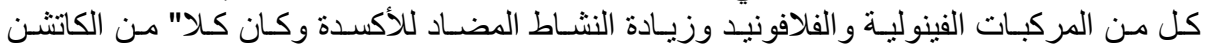

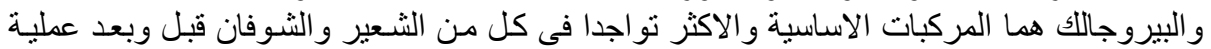

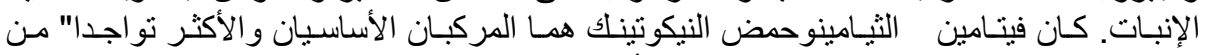

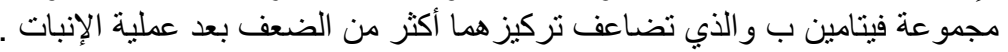

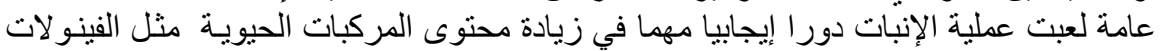

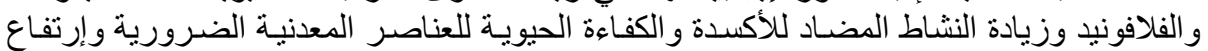
محتوى فيتامين ب المركب فى كل من الثعير والثوفان.

كلية الزراعة - جامعة المنصورة

قام بتحكيم البحث

مركز البحوث الزراعيه

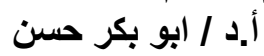

أ.د / فؤاد امين الاشوح 